Carlos Camponez

Ana Teresa Peixinho

Coordenação

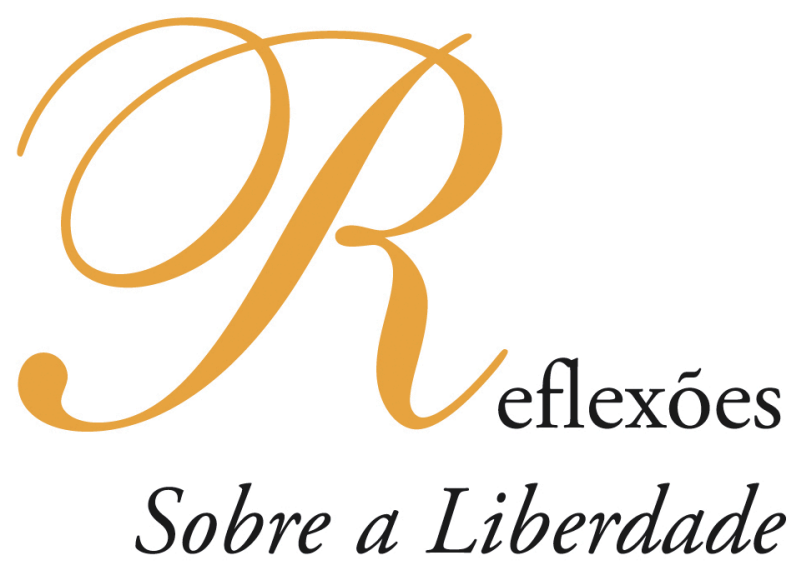

150 anos da obra de John Stuart Mill

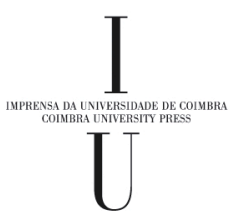




\section{John Stuart Mill V. Richard Dawkins: \\ A Liberdade de Expressáo e a \\ Crítica ao Paradigma Evolucionista Dominante}

Jónatas E.M. Machado

O presente artigo pretende assinalar uma dupla efeméride. Em 1859 publicaram-se no Reino Unido duas obras de importância assinalável. Uma foi The Origin of the Species, de Charles Darwin ${ }^{28}$, que lançou as bases do moderno evolucionismo naturalista. A outra foi o ensaio On Liberty, do filósofo inglês John Stuart Mill. Volvidos 150 anos da publicação de uma e outra, afigura-se importante investigar o modo como o evolucionismo e a liberdade de expressão e discussão aberta se cruzam um com um outro. Para esse efeito iremos confrontar as propostas dialógicas de John Stuart Mill com as teses de um dos mais acérrimos defensores do evolucionismo no século XX e XXI, Richard Dawkins, que até há alguns anos atrás ensinou na Universidade de Oxford. Procuraremos ver se e em que medida o evolucionismo de Richard Dawkins convive com a liberdade de discussão e de crítica às suas premissas naturalistas e materialistas. Para isso começaremos com uma síntese do pensamento de John Stuart Mill sobre a liberdade de expressão. Em seguida iremos ver a forma como Richard Dawkins encara o debate entre evolucionistas e criacionistas e o modo como a sua adesão à teoria da evolução se repercute negativamente sobre a própria liberdade de expressão. Finalmente apresentaremos a nossa avaliação crítica, sustentando a actualidade do essencial das propostas de John Stuart Mill no debate em torno da questão das origens, por sinal um dos mais importantes que o ser humano vem travando desde sempre.

O filósofo inglês John Stuart Mill destacou-se, no século XIX, pela sua defesa intransigente de uma ampla e robusta liberdade de expressão com base em argumentos de natureza racional e utilitarista. Temos em mente o seu ensaio On Liberty ${ }^{29}$, obra em que são aproveitados e desenvolvidos alguns dos argumentos articulados, cerca de dois séculos antes, por John Milton, em Areopagitica, na sua veemente defesa da liberdade de expressão contra a censura parlamentar.

A posição de John Stuart Mill marcou profundamente a época vitoriana num tempo de modernização social, florescimento da ciência, progresso técnico, urbanização e industrialização, caracterizado pela consciencialização da relevância do conhecimento científico para a superação de estruturas cognitivas e normativas tradicionais e a organização da vida social. Em nosso entender, os argumentos avançados por John Stuart Mill continuam a ser inteiramente pertinentes hoje. Tanto mais que não faltam hoje vozes que pretendem «dinamizar a discussão» no espaço público a partir da marginalização e do silenciamento das vozes discordantes. Assim sucede no caso dos defensores do novo ateísmo de base evolucionista.

Assiste-se hoje a uma tentativa assumida de promoção do pensamento único no domínio da discussão da questão das origens, com reflexos nas escolas secundárias, nas universidades e no espaço público mediático. Essa tentativa é principalmente encabeçada pelo decano do ateísmo evolucionista Richard Dawkins ${ }^{30}$. Daí que a mesma se apresente como

28 Charles Darwin, Julian Huxley, The Origin Of Species: 150th Anniversary Edition, New York, 2003.

29 John Stuart Mill, On Liberty and Other Essays, Oxford, 1991, 20 ss., esp. 22 ss.

30 Podemos dizer que Richard Dawkins herdou este título de Anthony Flew, o conhecido filósofo britânico 
o caso de estudo, por excelência, para testar a validade e a pertinência das teses de John Stuart Mill. Nas linhas que se seguem procuraremos sintetizar os principais argumentos a favor da liberdade de expressão mobilizados por este pensador liberal e contrapô-los às teses sustentadas por Richard Dawkins.

Para John Stuart Mill, dada a falibilidade e a provisoriedade do pensamento e do conhecimento humanos, nenhuma opinião, maioritária ou minoritária, deve ser silenciada, porque pode dar-se o caso de a mesma ser verdadeira e de se estar, dessa forma, a silenciar uma ideia verdadeira. A história mostra que muitas opinióes num dado momento tidas por verdadeiras se vieram a revelar erradas quando submetidas à crítica e ao confronto com outras opiniōes. E a inversa também é verdadeira, o mesmo sucedendo com a consideração de uma proposiçáo sucessivamente como sendo verdadeira ou falsa. Entre a verdade e a falsidade de uma dada proposição existe, por vezes, um movimento pendular. Para John Stuart Mill, mesmo que uma ideia seja efectivamente verdadeira (o que, como vimos, nem sempre é um dado isento de controvérsia), nem assim se justifica o silenciamento de ideias erradas.

Mesmo a expressão de uma opiniáo errada pode ajudar a refinar, a confirmar e a justificar racionalmente uma ideia correcta, prevenindo a sua transformação em dogma de aceitação acrítica. $\mathrm{O}$ contacto permanente entre a verdade e o erro permite que a aceitação daquela resulte da consciência clara da sua superioridade racional relativamente às opinióes divergentes e nunca de uma tradição, passível inclusivamente de a corromper e degradar com o tempo. Sem excluir a hipótese de mesmo uma ideia errada conter elementos verdadeiros. Assim sucede em muitos casos. Nem sempre é fácil delimitar de forma nítida e incontroversa, onde termina a verdade e onde começa o erro de uma afirmação. Muitas vezes ambos encontram-se entrelaçados, sendo necessário um trabalho crítico persistente, cuidadoso e frequentemente demorado para os desentranhar e separar.

John Stuart Mill defendeu que todo o exercício do poder coercivo restritivo da liberdade individual encontra o seu fundamento na protecçáo da sociedade de quaisquer danos reais iminentes que a mesma possa enfrentar. Para além disso, não existe qualquer outra razáo para restringir a liberdade. $\mathrm{O}$ aperfeiçoamento moral da sociedade pode ser conseguido, não pela força, mas pela argumentação, pela demonstração e pela persuasão. Nos processos dialógicos e conversacionais, os domínios íntimos da consciência devem prevalecer sobre o paternalismo do Estado. O exercício de uma ampla liberdade individual é visto como promovendo, a longo prazo, a maior utilidade para o maior número. O livre desenvolvimento individual afigura-se, não sem um certo optimismo, como a melhor garantia do livre desenvolvimento da humanidade ${ }^{31}$. O exercício de uma ampla liberdade individual, numa sociedade pluralista, encontra-se ao serviço, a longo prazo, da maior utilidade para o maior

que durante seis décadas se destacou na sofisticada defesa filosófica do ateísmo, nos mais diversos palcos mundiais. Recentemente, Anthony Flew decidiu rever a sua posição, aderindo ao deísmo, explicando as suas razóes no livro There Is a God, New York, 2007. Para ele, a existência de um Criador é uma posiçâo racional e cientificamente irrefutável porque 1) a existência de leis naturais no Universo corrobora uma criação racional; 2) a sintonia do Universo para a vida corrobora uma criaçáo racional; 3) a estrutura racional e matemática do Universo, da Vida e do Homem corrobora uma criaçáo racional; 4) a existência de informação semântica codificada no genoma corrobora uma criaçáo racional. Embora Anthony Flew não se tenha convertido a nenhuma religião em especial, ele confessa, nesta sua obra, que se há alguma religiāo digna de consideração séria, ela é o Cristianismo, em virtude daquilo que diz ser a "figura carismática» de Jesus Cristo e o «super-intelecto» do Apóstolo Paulo.

31 Se esse optimismo é justificado em todas as circunstâncias é uma outra questão, que achamos por bem não considerar neste momento. 
número ${ }^{32}$. A retórica de John Stuart Mill sugere que, mesmo do ponto de vista meramente pragmático e utilitarista, existe um perigo óbvio na supressão das opinióes.

A compreensão ampla e robusta da liberdade de expressão propugnada por John Stuart Mill pretende valer em todas as áreas em que possam existir opiniōes divergentes. Não admira, por isso, que John Stuart Mill procure exemplos paradigmáticos daquilo que pretende sustentar dentro das esferas religiosa e científica, tantas vezes compreendidas e tematizadas como estando em oposição. Com isso, ele começa por reconhecer que mesmo na esfera religiosa, tantas vezes acriticamente confundida com a intolerância e o dogmatismo, há lugar para a tensão dialógica e crítica. Têm aqui total pertinência as palavras de John Stuart Mill, no seu ensaio On Liberty, para quem «the most intolerant of the churches, the Roman Catholic Church, even at the canonization of a saint, admits, and listens patiently to, a "devil's advocate». The holiest of man, it appears, cannot be admitted to posthumous honours, until all that the devil can say about him is known and weighed. If even the Newtonian philosophy were not permitted to be questioned, mankind could not feel as complete assurance of its truth as they now do».

Neste trecho, John Stuart Mill consegue discernir na própria Igreja Católica, que ele qualifica como a mais intolerante das Igrejas, a noção de que nas questóes mais importantes para esta confissão religiosa, mesmo aquilo que parece evidente e desejável, como a canonização de um santo, deve ser sujeito ao contraditório e ao exame crítico contundente. É claro, que John Stuart Mill não deixa de notar a intolerância religiosa que em seu entender caracterizava a Igreja Católica. A sua referência parece ter, entre outros, o objectivo de evidenciar alguma inconsistência e contradição interna entre as doutrinas cristãs e a prática da Igreja Católica no domínio da liberdade de expressão. Em todo o caso, os debates teológicos que ao longo dos séculos se vêm travando, sobre os mais variados temas, dentro e entre as confissóes religiosas, confirmam que, a despeito de práticas institucionais, indesmentíveis, de intolerância e perseguição, a religião em si mesma nunca foi um espaço para o monolitismo discursivo acrítico, como por vezes se pretende sugerir.

Para além disso, as palavras de John Stuart Mill remetem para o domínio da ciência e da confrontação de ideias dentro desse espaço, através de um outro exemplo também deliberadamente extremado. Em seu entender, mesmo a filosofia newtoniana, cuja veracidade ninguém disputava no seu tempo, deveria poder ser abertamente questionada, a fim de ser testada no confronto das ideias. Como é sabido, Isaac Newton foi um dos maiores cientistas de todos os tempos. Convencido de que a ciência consistia em pensar os pensamentos de Deus depois de Deus, Newton desenvolveu a teoria da gravitação universal e as suas três leis do movimento. Além disso, ele demonstrou matematicamente que essas leis se aplicam igualmente aos céus e à Terra. Os princípios desenvolvidos por Isaac Newton foram considerados durante muito tempo uma descrição correcta da realidade. O próprio John Stuart Mill estava convencido da inatacabilidade dos seus fundamentos científicos. Por isso mesmo ele invocou Newton no seu exemplo.

O seu objectivo consistia em defender que mesmo uma teoria, como a de Isaac Newton, geralmente considerada factualmente correcta e imune à refutação, deveria ser continuamente sujeita a exame crítico e ao confronto com outras ideias. Isso só iria contribuir para

32 Jeremy Waldron, «Religious Contributions in Public Deliberation», 30, San Diego Law Review, 1993, 817 ss. e 836 ss, discutindo o papel da discussão de assuntos religiosos à luz da concepção de mercado das ideias de John Stuart Mill. 
confirmar e reforçar o seu estatuto de correcção científica, assegurando permanentemente as pessoas acerca da sua confiabilidade. De acordo com John Stuart Mill, mesmo que uma opinião seja tida por factualmente correcta pela maioria, ainda assim importa que ela mantenha o contacto com as ideias incorrectas e seja achada superior a elas.

Os desenvolvimentos posteriores viriam dar razão à insistência de John Stuart Mill na liberdade de discussão, embora desmentissem a sua crença na inatacabilidade de Isaac Newton. Afinal, a filosofia newtoniana, considerada inatacável no seu tempo, tem vindo a evidenciar importantes insuficiências. Por isso a mesma tem vindo a ser progressivamente complementada e substituída por novos modelos, teóricos, como a teoria da relatividade geral e especial, a física quântica ou a(s) teoria(s) das cordas. Ou seja, mesmo aquilo que é considerado verdadeiro pela maioria dos cientistas numa dada época nunca pode deixar de ser livre e abertamente questionado. A concordância da maioria, só por si, não é suficiente para estabelecer a verdade de uma proposição. A presunção da verdade de uma determinada afirmação depende sempre da sua capacidade para resistir, na esfera de discurso público, a afirmaçốes que possam ser feitas em sentido contrário. Neste sentido, a presunção de verdade de uma afirmação nunca pode ser o resultado do proteccionismo intelectual, que procure impermeabilizar essa afirmação à crítica e isolá-la de toda a discussão.

Para John Stuart Mill ${ }^{33}$, uma coisa é presumir que uma afirmação é verdadeira porque a mesma não foi refutada apesar de existirem todas as oportunidades para o fazer. Daí resulta a convicção da sua maior aptidão, na medida em que conseguiu superiorizar-se a outras ideias menos aptas. Ainda assim, trata-se apenas de uma presunção de verdade, ilidível pela emergência de posteriores observaçóes, conhecimentos e modelos explicativos. Outra coisa, muito diferente, é partir do princípio de que uma doutrina é verdadeira, com o objectivo de impedir que a mesma possa ser abertamente discutida e refutada. Isto já é absolutamente ilegítimo. Esta era uma prática recorrente no tempo de John Stuart Mill, contra a qual este se insurgia de forma veemente. A mesma era associada ao dogmatismo autoritário de algumas instituiçôes religiosas e políticas. Ela era incompatível com a liberdade de consciência e com a autodeterminação individual e colectiva. A mesma manifestava-se na condenaçáo de hereges, apóstatas e cismáticos ou na existência de delitos de opinião e na perseguição política. Para John Stuart Mill nenhuma ideia, independentemente da sua natureza e do seu conteúdo, poderia ser presumida como verdadeira e usada para fundamentar, a partir dessa presunção, a perseguição e o silenciamento das ideias opostas. Nenhuma afirmação pode ser protegida da crítica e da refutação. Nenhuma questão transita verdadeiramente em julgado no tribunal da razão humana. Para Mill não havia lugar para máximas como «Roma Locuta causa finita».

Em face deste entendimento, o recente livro The Greatest Show on Earth, Evidence of Evolution, de Richard Dawkins, constitui um interessante teste à relevância actual do ensaio On Liberty, de John Stuart Mill. O mesmo coloca importantes desafios à liberdade de pensamento e de expressão, tão valorizados por este importante filósofo liberal e utilitarista do século XIX. Em Richard Dawkins, um dos mais proeminentes ateus evolucionistas da actualidade, encontramos uma atitude diametralmente oposta à preconizada por John Stuart Mill. A estratégia de Richard Dawkins para a promoção da teoria da evolução das espécies, consiste na defesa do silenciamento de todas as opinióes que lhe sejam contrárias, em franco contraste com a abertura racional e dialógica que John Stuart Mill demonstrava

33 Mill, On Liberty and Other Essays, ed. cit., p. 24. 
em todas as matérias. Daí que nos pareçam relevantes algumas consideraçóes de enquadramento, para que se possa compreender a relação entre aquela obra e o pensamento de John Stuart Mill.

Richard Dawkins é um conhecido Professor de Oxford que ao longo de várias décadas tem vindo a defender ardentemente a teoria da evolução das espécies, como fundamento do ateísmo, com base em livros como The Selfish Gene, The Devil's Chaplain, Climbing Mount Improbable, The Ancestor's Tale, etc. O seu penúltimo livro deu pelo nome The God Delusion, evidenciando um ateísmo militante que mesmo alguns ateus consideram extremista. Particularmente interessante é o facto de o alvo primordial do seu ataque ser o Deus da Bíblia, de quem se diz que criou o Universo em seis dias e descansou ao sétimo dia; que terá castigado a humanidade com um dilúvio global, há cerca de 4500 anos; que terá escolhido Abraão, Isaque e Jacó, a quem mudou o nome para Israel, para assinalar a sua presença na História; de quem os escritos antigos dizem ter encarnado na figura histórica de Jesus Cristo, por sinal a mais influente em toda a história da humanidade. É este Deus, e não outro, que incomoda profundamente Richard Dawkins.

Curiosamente, Richard Dawkins não deixa de censurar moralmente esse Deus, de uma forma veemente, embora sem nunca explicar onde vai buscar a superioridade e autoridade moral para o fazer, nem o necessário critério objectivo de moralidade para realizar essa tarefa de forma bem sucedida. Tanto mais, quanto é certo que Richard Dawkins reconhece que num universo sem Deus toda a moralidade é o resultado de preferências subjectivas relativas e iguais entre si. Pelo que, teríamos apenas um confronto entre as preferências subjectivas de Richard Dawkins e as dos autores da Bíblia, sem qualquer critério objectivo para decidir do mérito de umas e outras. Não obstante, aquele que pretende ser o seu argumento central, sobre "a radical improbabilidade de um Deus mais complexo do que o Universo", dá mostras de uma ingenuidade retórica pueril, que pode convencer os incautos mas que é facilmente neutralizável com argumentos filosóficos e teológicos básicos. Talvez por estar consciente dessa fraqueza substancial da sua argumentação Richard Dawkins tenha sentido a necessidade de, pouco tempo depois, editar um novo livro sobre a teoria da evolução. A afirmação de que Deus não passa de uma ilusão, um delírio ou uma alucinação radicalmente improvável, seria insuficiente para resolver a questão.

O capítulo introdutório do livro The Greatest Show on Earth começa com a confissão de que em todos os livros anteriores Richard Dawkins sempre assumiu a evolução, sem ter realmente apresentado evidência de evolução. Esta confissão é apropriada e só vem corroborar aqueles que desde há muito vinham dizendo isso mesmo sobre a obra de Richard Dawkins. Neste último trabalho, Richard Dawkins propóe-se finalmente apresentar aquilo que ele designa como o "elo em falta», em toda a sua obra: toda a evidência da teoria da evoluçáo, que ele julga ser esmagadora. Nem por isso ele deixa de intensificar o seu ataque ad hominem aos criacionistas. Esta estratégia evidencia, provavelmente, alguma insegurança relativamente à posição que pretende sustentar. Os argumentos científicos parecem não ser suficientes, sendo necessário o esforço ulterior de denegrir quem deles discorde. Não é este o momento de discutir a questão de saber se a evidência apresentada no livro The Greatest Show On Earth é realmente esmagadora, como pretende o autor, ou até mesmo a questão de saber se se está aí realmente perante evidência de evolução ou apenas diante de evidência da adesão $a$ priori a uma visão naturalista do mundo, que descarta à partida a existência de Deus e que, consequentemente, interpreta os escritos bíblicos, os seres vivos, as rochas, os fósseis e os isótopos como se Deus não existisse e como se não se revelasse na história humana. 
Interessante, para o tema da liberdade de discussão e de expressão, é a tentativa empreendida por Richard Dawkins no sentido de estigmatizar e ridicularizar os seus opositores criacionistas, por sinal os principais visados nas suas diatribes. Provavelmente o objectivo consiste em levar as pessoas a não quererem sequer ouvir os contra-argumentos que possam ser mobilizados contra a perspectiva evolucionista, a partir de várias frentes, de natureza histórica, científica, filosófica, epistemológica e teológica. No seu entender, importa que a perspectiva evolucionista seja apregoada sem contestação, conseguindo uma posição monopolista na esfera de discurso público. Já há muito que Richard Dawkins vinha sustentando que quem não acredita na teoria da evolução o faz apenas porque é «ignorante, estúpido ou louco (ou perverso) ${ }^{34}$ ».

Na obra The Greatest Show On Earth, o autor vilipendia asperamente todos quantos pretendam discutir a evidência por ele apresentada. A sua estratégia de combate poderia ser resumida assim: «deixo-vos aqui as evidências da evolução das espécies, juntamente com o apelo para que não dêem ouvidos a todos quantos as pretendam discutir e refutar. Confiem em mim». A par de uma apresentação de factos observáveis acompanhados da sua interpretação evolucionista (curiosamente alguns deles refutados escassas semanas após a publicação do livro) Richard Dawkins procura desferir um violento ataque ad hominem aos opositores da teoria da evoluçáo das espécies, na expectativa de que isso seja suficiente para blindá-la contra qualquer discussão ou crítica.

Para além da estratégia tradicional de dirigir insultos e impropérios aos opositores da teoria da evolução das espécies, particularmente àqueles que defendem um criacionismo recente compatível com os escritos bíblicos, Richard Dawkins procura apresentá-los como negadores da história, equiparados aos actuais negadores do Holocausto e a hipotéticos negadores do Império Romano, não merecendo por isso um espaço igual na esfera pública, nas universidades e nas escolas públicas e privadas. Pelo contrário, a estratégia de Dawkins aponta no sentido da sua colocação sob apertada supervisão estadual, como se depreende de uma carta citada pelo próprio, redigida ao então Primeiro-Ministro britânico Tony Blair, em que se defendeu a vigilância atenta de uma escola cristá, britânica, em que o criacionismo era ensinado a par do evolucionismo. Curiosamente, esta era uma escola onde os alunos tinham obtido excelentes classificaçôes nos exames nacionais das disciplinas científicas.

A novidade retórica apresentada por Richard Dawkins consiste em aproveitar-se da polémica em torno dos negadores do Holocausto e procurar estendê-la a quantos negam a teoria da evolução das espécies. Uns e outros teriam em comum a irracionalidade de negarem factos historicamente comprovados. Para conferir maior plausibilidade a este truque retórico, Richard Dawkins convida o leitor a imaginar o que seria ter professores das Universidades ou escolas secundárias que negassem a existência do Império Romano, embora não se conheça ninguém nessas condiçôes. $\mathrm{O}$ essencial do seu argumento é: se é absurdo negar o Holocausto ou o Império Romano, também o é negar a evolução das espécies, na medida em que se trata nos três casos de factos objectivamente comprovados. Embora o negacionismo histórico seja agora a principal estratégia para denegrir e degradar todos quantos rejeitam a evoluçáo das espécies, ao longo da sua obra o autor recorre frequentemente a outras técnicas de estigmatização, não se coibindo de chamar «ignorantes» e mesmo "perversos» a todos quantos pretendam argumentar contra a teoria da evolução.

34 «Put Your Money on Evolution», The New York Times Review of Books, April 9, 1989, pp. 34-35. Apud John Lennox, God's Undertaker Oxford, England: Lion Hudson, 2007, p. 93. 
Em todo o caso, a estratégia argumentativa adoptada por Richard Dawkins traz, em si mesma, as sementes da sua própria refutação. Em primeiro lugar, porque ela pretende apelidar de negadores da história precisamente aqueles que mais a sério levam o testemunho inscrito em documentos antigos de fidedignidade histórica e arqueologicamente comprovada ao longo dos séculos. Nos escritos bíblicos, canónicos e apócrifos, encontram-se detalhadas referências históricas aos povos da Mesopotâmia e do Médio Oriente, bem como aos impérios egípcio, assírio, babilónio, persa, grego e romano. Por sua vez, nos escritos do Novo Testamento são feitas referências precisas e historicamente comprováveis a figuras (b.g. César Augusto, Quirino, Pilatos, Félix e Festo), locais (v.g. Cesareia; Roma) e instituiçôes jurídicas do Império Romano (v.g. pena de morte por crucificação, recurso para César). Não se conhece qualquer cientista, historiador ou líder religioso que negue a existência do Império Romano. Daí que não faça qualquer sentido equiparar a rejeição da evolução das espécies à negação hipotética do império romano. Trata-se aí de um artifício de retórica sofística, de uma forma de pirotecnia argumentativa, com o único objectivo de deslumbrar, atordoar e distrair os leitores.

Do mesmo modo, a corrente negacionista do Holocausto é menos notável hoje por se tratar de um movimento dotado de pretensóes historiográficas consistentes e plausíveis, do que por ser um ataque deliberado e malicioso à dignidade do povo judeu e à subsistência do Estado de Israel, criado 10 anos depois da Noite de Cristal, por sinal realidades sobre as quais amplamente se discorre nos escritos hebraicos, precisamente aqueles que estáo na mira do ataque sistemático de Richard Dawkins. Por outras palavras, não se afigura descabido afirmar que Adolph Hitler pretendia uma «solução final» para os judeus, ao passo que Richard Dawkins pretende uma «solução final» para os escritos hebraicos que fundamentam a identidade dos judeus, a começar pelos primeiros capítulos do livro de Génesis. Uma análise da obra de Richard Dawkins permite concluir que estes escritos, e não qualquer outra obra religiosa ou mitológica da antiguidade, são os principais visados pelas suas diatribes. Este padrão não deixa de ser intrigante e significativo, especialmente quando avaliado à luz da narrativa teológica contida nos textos bíblicos.

Richard Dawkins acusa os opositores da teoria da evolução de negarem a história, quando ele próprio rejeita importantes relatos históricos, pessoal e geograficamente referenciados e circunstanciados, de alguns dos eventos, locais e personagens mais marcantes da história da humanidade, cuja relevância é ainda hoje decisiva para compreender alguns dos mais difíceis problemas que a humanidade enfrenta no século XXI. A verdade é que se fossemos a fazer a história do Holocausto, que aconteceu há apenas 60 anos, com base unicamente na análise científica de ossos e crânios, desconsiderando todos os testemunhos históricos, como parece ser a metodologia preferida por Richard Dawkins, estaríamos muito mal. Com efeito, recentemente descobriu-se que o crânio que durante anos se dizia ser de Adolph Hitler era, afinal, de uma mulher! ${ }^{35}$

No entanto, existe um ponto crucial em que a pretensa analogia que Richard Dawkins procura estabelecer entre a negação do Holocausto e a negação do Império Romano é destruída pela argumentação do próprio. O Holocausto aconteceu há escassas décadas, havendo dele amplas e consistentes evidências físicas, cinematográficas, documentais e relatos

35 «Fresh Doubts Over Hitler's Death After Tests on Bullet Hole Skull Reveal It Belonged to a Women», Mail Online, Mail Foreign Service, 28 de Setembro de 2009; "DNA test shows Hitler skull is that of a woman", Word News.com.au, 29 de Setembro de 2009. 
de testemunhas oculares, algumas delas ainda vivas. Por sua vez, do Império Romano surgem-nos, não apenas uma grande quantidade de documentos históricos, para além de vestígios arqueológicos e arquitectónicos muito bem preservados em toda a Europa e praticamente ao longo de toda a bacia mediterrânica. O problema de Richard Dawkins é que, como o próprio reconhece expressamente, ninguém testemunhou a origem acidental da vida nem a evoluçáo das espécies a partir de um antepassado comum, nem documentou o respectivo processo. Esta é uma diferença fundamental que inviabiliza a analogia de Dawkins entre os negadores, reais ou hipotéticos, do Holocausto e do Império Romano e aqueles que rejeitam a teoria da evolução das espécies. O Império Romano e o Holocausto foram observados e documentados historiograficamente por muitos. A origem acidental da vida e a evolução das espécies a partir de um antepassado comum nunca foram observados por ninguém, resultando de inferências e extrapolaçóes feitas no presente, por pessoas que vivem no presente, a partir de dados observados no presente, com base em visóes do mundo sustentadas no presente.

Para o próprio Richard Dawkins, a evolução das espécies é como um crime que ninguém presenciou e que apenas deixou vestígios que devem ser hoje apresentados num tribunal. Dito de outro modo, Richard Dawkins compara a evolução das espécies com a cena de um crime que terá acontecido no passado, não observado, com todos os vestígios diante de nós. Repare-se, porém, que Richard Dawkins começa logo por avançar a ideia de que houve um crime, mesmo quando sublinha que ninguém presenciou o evento. Mas entáo como é que ele sabe? Como é que ele pode assegurar a priori que se tratou realmente de um crime? A retórica de Richard Dawkins denuncia o facto de que ele parte para as evidências com uma ideia pré-concebida! Sucede que, mesmo no seu exemplo, a ocorrência de um crime deveria resultar de uma inferência feita a posteriori, a partir das evidências recolhidas. Mas ainda assim trata-se apenas uma interpretação possível da presença de um cadáver.

A experiência ensina-nos que numa alegada cena de um crime nem tudo é o que parece. Para uns pode ser óbvio ter-se tratado de um crime. Outros poderão sustentar que a evidência é mais facilmente compatível com a ocorrência de um acidente ou de um suicídio. Por outro lado, mesmo tratando-se de um crime, o criminoso pode ser quem menos se espera. É necessário analisar cuidadosamente toda a evidência, examinar atentamente todos os pontos de vista e sujeitar os vários argumentos a uma análise crítica rigorosa. E mesmo as decisóes de condenação podem ter que ser reabertas diante de novos dados. Da mesma maneira, a evolução das espécies, não tendo sido observada por ninguém, é apenas uma interpretação possível da informação codificada no genoma, das similaridades genéticas, dos fósseis, das rochas, dos isótopos, etc. Todavia, não está excluída a existência de outras interpretaçóes para os mesmos dados empíricos observáveis. Nem se pode descartar muitos dados novos que todos os dias vêm obrigar a rever teorias e modelos dominantes. Em última análise, a interpretação que é feita dos dados observados é indissociável das crenças com que se parte sobre o que terá acontecido no passado distante não observado. A metodologia de John Stuart Mill, para quem mesmo as ideias tidas como certas deviam estar abertas à discussão e à crítica, revela-se de inteira relevância nesta temática.

Ao tentar silenciar os criacionistas, chamando-lhes falsamente «negadores da história», Richard Dawkins quer chegar sozinho àquilo que designa a priori como uma «cena do crime». Com base nas suas ideias pré-concebidas ele pretende poder livremente escolher as evidências que mais lhe interessam, por corroborarem a sua convicção de que houve um crime, e interpretá-las do modo que acha conveniente e apresentar a sua versão ao juiz, 
só ele, sem mais ninguém. Ele não quer que ninguém o confronte com outras evidências para além das que ele considera relevantes, nem com outras interpretaçóes possíveis para a evidência apresentada.

Richard Dawkins compara a defesa da teoria da evolução com a ideia de que se trata algo como apresentar as evidências de que houve um crime a um tribunal. Escusado será dizer que em qualquer tribunal digno desse nome, a metodologia proposta por Richard Dawkins seria inaceitável. Um juiz imparcial iria sempre admitir todas as provas que lhe fossem trazidas pelas partes na controvérsia e todas as inferências produzidas com base nelas. Só assim seria possível determinar, para além de qualquer dúvida razoável, se realmente houve crime e, se foi esse o caso, quem foi o criminoso. Ou seja, uma avaliação independente e imparcial nunca consideraria decisivo o facto de uma das partes de uma controvérsia estar convencida da bondade dos seus argumentos para, a partir daí, tentar impor a sua tese e silenciar as opinióes divergentes. Num tribunal são sempre admitidos argumentos e contra-argumentos, porque os vestígios não falam por si. São sempre os intervenientes no processo que falam por eles.

Richard Dawkins é um daqueles autores que assume que as suas concepçôes são verdadeiras, não porque as mesmas não sejam passíveis de discussão e crítica, mas para que as mesmas não sejam passíveis de discussão e crítica. Neste sentido, ele coloca-se claramente nos antípodas da abertura intelectual e conversacional preconizada por John Stuart Mill. Esta posição de partida tem levado Richard Dawkins a recusar-se a defender publicamente o seu mais recente livro nos debates com cientistas criacionistas para que tem sido desafiado ${ }^{36}$. Naturalmente, depois de lhes chamar negadores da história, ignorantes, estúpidos, loucos ou perversos, Richard Dawkins teria alguma dificuldade em explicar aos seus seguidores porque é que aceitaria discutir com eles.

Essa estratégia é particularmente conveniente, porque lhe permite granjear uma aura de superioridade racional e científica, sem ter que se sujeitar à incerteza do confronto directo com os seus opositores. Para dar uma aparência de sustentabilidade teórica à sua posição de fuga ao confronto com os críticos da teoria da evolução das espécies, Richard Dawkins chega mesmo a lançar as bases de uma teoria da liberdade de expressão a partir das suas próprias premissas evolutivas. Para ele é claro que «Darwin locuta, causa finita!». Em vez de sujeitar as premissas evolucionistas à discussão, Richard Dawkins coloca-as como fundamento e limite da discussão.

Isso é conseguido a partir da concepção «memética» da liberdade de expressão. Richard Dawkins compara as ideias, que designa por «memes», aos genes, desse modo enfatizando o seu carácter auto-replicante e a sua capacidade para ganharem vida própria, escapando ao controlo dos próprios indivíduos que as produzem ${ }^{37}$. De acordo com esta concepção, as ideias seriam replicadores impessoais sem qualquer vínculo necessário à mente huma$\mathrm{na}^{38}$. Apesar de o argumento de Richard Dawkins ter o mérito de acentuar os elementos competitivos da luta de ideias, o mesmo não deixa de ter as suas fragilidades. Desde logo, ele apoia-se numa redução naturalista das ideias a meros estados cerebrais, ou a processos

36 World atheist convention rejects Australian creationist debate challenge, by Dr Carl Wieland, Published: 1 January 2010(GMT+10) http://creation.com/global-atheists-reject-debate-challenge

37 Richard Dawkins, The Extended Phenotype: The Long Reach of the Gene, Oxford University Press, 1999, p. 97 ss.

38 Jeffrey Evans Stake, "Are We Buyers or Hosts? A Memetic Approach to the First Amendment", 52, Alabama Law Review, 2001, p. 1213. 
físico-químicos, podendo conduzir, se levada às suas últimas consequências, à negação da própria racionalidade humana.

Além disso, este argumento ignora o facto de que, no contexto das ideias, a selecção operada, longe de se basear em processos aleatórios e naturais, é sempre mediada pela experiência, pela inteligência e pelos interesses humanos. De resto, muitos casos há em que as ideias que triunfam não são necessariamente as mais aptas, quando tomadas em si mesmas, mas simplesmente aquelas que resultaram do triunfo ideológico e coercivo dos grupos sociais política, económica e militarmente mais poderosos numa determinada conjuntura histórica. Diante desta realidade, a despersonalização e a autonomização das ideias como simples replicadores, desvalorizando a humanidade da sua génese, pode ser utilizada para justificar a censura das ideias que sejam pontualmente consideradas como nocivas e perigosas. E isso, a pretexto de se estar, desse modo, apenas a censurar ideias e não a silenciar pessoas, na sua qualidade de titulares do direito à liberdade de expressão. Como se vê, Richard Dawkins não apenas pretende promover dogmaticamente a teoria da evolução das espécies, furtando-a a toda a discussão, como não se coíbe de construir uma teoria evolucionista da liberdade de expressão "feita à medida», onde as perspectivas contrárias são consideradas simples "vírus» meméticos auto-replicantes que devem ser «apagados» por serem considerados prejudiciais ${ }^{39}$. Este entendimento está claramente nos antípodas da concepção dialógica aberta e desinibida de John Stuart Mill. É claro, neste momento, que o ateu evolucionista Richard Dawkins está longe de partilhar da mesma convicção forte de uma ampla liberdade de discussão.

A questão das origens, com especial relevo para o debate entre as teses opostas de criação e evolução, é hoje daquelas que gera uma das mais acesas controvérsias. John Stuart Mill seria certamente o primeiro a afirmar que essa discussão deve ser levada a cabo de forma livre e aberta. Em sentido contrário, Richard Dawkins pretende sugerir que a teoria da evolução não apenas deve ser aceite sem discussão, como deve fundamentar e limitar toda e qualquer discussão. Para ele, qualquer opinião que seja mobilizada contra a teoria da evolução das espécies é absolutamente inútil e indigna de consideração. Richard Dawkins está inteiramente convencido de que a afirmação da evolução das espécies é única proposição verdadeiramente útil e digna de consideração. Mas será realmente assim? Pemitimo-nos, a este propósito, traduzir livremente John Stuart Mill, quando este observa que «a utilidade de uma opinião é, em si mesma, uma questão de opinião: tão questionável, tão aberta à discussão pública, tão carecida de discussão como a opinião em si mesma». Por outras palavras, a opinião de que a evoluçáo é um facto ou de que nada na biologia faz sentido sem a teoria da evolução não passam de opiniốes questionáveis e abertas à discussão.

Em teoria, é tão legítimo sustentar que a evidência de evolução revela um mundo sem design, como a proposição contrária, de que a evidência de design revela um mundo sem evolução. Sobre os defensores destas diferentes posiçôes impende o mesmo ónus da fun-

39 Um outro problema é que a tese dos «memes» conduz, em última análise, a que a teoria da evoluçâo e a tese dos «memes» sejam reduzidas elas próprias à categoria de simples vírus auto-replicante, de relevância impessoal, acabando por rebaixar o seu estatuto intelectual e epistemológico. $\mathrm{Na}$ verdade, o risco de degradação racional e epistemológica já há muito anda associado à teoria da evolução. O próprio Charles Darwin reconheceu o problema quando indagou: «But then with me the horrid doubt always arises whether the convictions of man's mind, which has been developed from the mind of the lower animals, are of any value or at all trustworthy. Would any one trust in the convictions of a monkey's mind, if there are any convictions in such a mind?», Letter $13230-$ Darwin, C. R. to Graham, William, 3 July 1881. 
damentação racional e empírica e da persuasão pública, independentemente das mundividências que possam estar subjacentes a uma e a outra. Nenhuma destas questóes se pode considerar encerrada por «decreto", com base numa qualquer noção de proteccionismo epistémico. Admitir a livre circulação de ideias sobre a origem do Universo, da Vida e do Homem que não pressuponham a existência de um Criador, ou designer inteligente, e proibir todas as teorias que explorem a possibilidade da existência de um tal Criador ou designer, não é compatível com uma concepção ampla e aberta da liberdade de expressão e discussão. A questão das origens é táo importante e estimulante que deveria ser livremente analisada e debatida no espaço público, num contexto exploratório, que não de doutrinação, onde todos os argumentos possam ser livremente mobilizados e contestados ${ }^{40}$. A essência da liberdade de expressão consiste justamente em garantir que todas as ideias fiquem sujeitas ao debate e à crítica no mercado livre das ideias, de forma a assegurar que só as mais aptas sobrevivem. Seria extraordinariamente irónico que (logo) o darwinismo, que apregoa a sobrevivência do mais apto, pretendesse permanecer imune à discussão, à crítica e à comparação com modelos explicativos alternativos.

Em conclusão, pode observar-se que Richard Dawkins passa uma boa parte do seu tempo a dizer que as pessoas náo devem escutar os criacionistas, devendo pensar por elas próprias. Para ele, isso parece significar que apenas o devem escutar a ele quando se trata de discutir a questão da origem do Universo, da vida e do ser humano. Em contraposição, John Stuart Mill diria que as pessoas podem e devem apresentar e discutir livremente todas as opinióes, submetendo-as à crítica pela contraposição de umas com as outras, mesmo quando as mesmas parecem ser inatacáveis, e tomando em seguida as suas decisóes autonomamente. Este procedimento dialógico aberto tem o mérito de contribuir para a validação das convicções individuais ao mesmo tempo que afirma os valores da racionalidade e da autonomia humanas. O mesmo não sucede com a tese sustentada por Richard Dawkins, que conduz à despersonalização das ideias e facilita a censura daqueles que forem contrárias ao paradigma evolucionista dominante. A tese de John Stuart Mill continua a ser a mais amiga da liberdade de expressão e da dignidade da pessoa humana. Curiosamente, já o Apóstolo Paulo recomendava a mesma metodologia quando recomendava aos cristãos de Tessalónica: «examinai tudo e retende o bem $»^{41}$.

40 Veja-se, designadamente, Thomas Nagel, «Public Education and Intelligent Design», Philosophy \& Public Affairs, Vol. 36, issue 2, 2008, considerando plenamente constitucional a discussão das hipóteses de criação (intelligent design) nas escolas públicas.

41 I Tessalonicenses 5:21. 